\title{
https://doi.org/10.46813/2021-136-085 \\ RADIATION LOSS DETERMINATION AT COLLISION OF ELECTRONS WITH ELECTRONEGATIVE ATOMS AND IONS IN PLASMA CURRENT SWITCH DISCHARGES. PART II
}

\author{
E.I. Skibenko, V.B. Yuferov, A.N. Ozerov, I.V. Buravilov \\ National Science Center "Kharkov Institute of Physics and Technology", Kharkiv, Ukraine \\ E-mail: skibenko38@gmail.com; ozerov@kipt.kharkov.ua
}

Specific radiation-loss power values have been determined for a variety of electronegative elements $(\mathrm{C}, \mathrm{O}, \mathrm{F}, \mathrm{Cl})$ as functions of electron temperature and impurity particle concentration. The maximum radiation-loss power level has been registered for chlorine $\left(\leq 770 \mathrm{~W} / \mathrm{cm}^{3}\right)$ at an electron/impurity density of $10^{14} \mathrm{~cm}^{-3}$. The minimum radiationloss power level for the other three elements lies in the range from 0.4 to $2 \mathrm{~W} / \mathrm{cm}^{3}$. Considerable radiation losses due to the presence of electronegative elements in the interelectrode discharge may lead to its destabilization, to the change in the plasma parameters $\left(n_{e}, T_{e}\right)$, and eventually, to degradation of the current-voltage characteristic of the plasma current switch.

PACS: 52.25.Jm; 52.50.Dg; 41.75.Ak

As indicated previously [1 - 7], the spectral composition of the residual atmosphere inside the vacuum chamber may exhibit, apart from the natural-origin elements, the elements of the electronegative Mendeleyev's group. These elements may appear as results of surface desorption and sputtering of individual units and components of the facility, including the plasma guns involved in the experiment [1 - 8], and also, due to the external and internal gas puffing. Therefore, it was of interest to estimate the effect of the mentioned factors on the radiative energy loss value with the involvement of electronegative elements $\mathrm{C}, \mathrm{O}, \mathrm{F}, \mathrm{Cl}$.

The radiation losses can be, and are, in fact, the most essential mechanism of energy loss [9 - 11] in astrophysical plasma, as well as in the laboratory and fusion plasmas [12 - 21]. The radiation manifests itself in different forms, viz., line emission, recombination radiation, bremsstrahlung, i.e., the radiation specified by various electron transitions in the fields of positive ions (bound-bound, free-bound, and free-free transitions). To calculate the power loss by radiation, the following basic assumptions and suppositions are made.

1. The plasma is optically thin with respect to its self-radiation. In this case, it is believed that the photon emission probability is greater than the probability of collisional deexcitation.

2. The effects associated with the presence of magnetic field in the plasma are neglected, i.e., the cyclotron radiation contribution to the total loss power is ignored.

3. The plasma density is chosen such as the stepwise ionization via excited states could be neglected. In other words, the energy, expended by electrons for excitation, is always lost as radiation.

4. The presence of metastable levels is ignored, even though they affect the ionization equilibrium and the intensity of spectral lines. It is thought that all the ions immediately turn into the ground state, and the metastable levels can be neglected.

5. With the assumption made about the existence of the steady-state ionization equilibrium, the problem becomes essentially simplified.

For each of the three forms of radiation (line emission, recombination, bremsstrahlung), the radiation by itself is the result of electron-ion collision. So, the total radiated power is equal to

$$
W=n_{e} n(A) P(A),
$$

where $n_{e}$ is the electron density, $n(A)$ is the total concentration of the impurity element $A, P(A)$ is the loss power function for the element $(A)$. The loss power function in its complete form is written as

$$
P_{A}=\sum_{z=0}^{z_{0}} \frac{n(A, z q)}{n(A)} P(A, z),
$$

where $P(A, z)$ is called the loss power coefficient for the ion $A(z)$.

The total radiative loss power for $\mathrm{z}$-charge ions from the unit plasma volume includes the line-radiation, photorecombination, bremsstrahlung, an also, the radiation accompanying dielectronic recombination of positive atomic ions and charge exchange. The dielectronic recombination contribution will be different in the case of rarefied and dense plasma. In general terms, the coefficient $P(A, z)$ is written as

$$
P(A, z)=P_{L}(A, z)+P_{R}(A, z)+P_{B}(A, z),
$$

where $P_{L}(A, z), P_{R}(A, z), P_{B}(A, z)$ are, respectively, the line-radiation, recombination, bremsstrahlung components of the loss power coefficient. The term $P_{L}(A, z)$ represents the sum over all possible lines arising at excitation. As a result, we obtain the function having the general form

$$
P_{L}(A, z)=\sum p X(g, p) \Delta E(g, p),
$$

where $X(g, p)$ is the direct excitation rate, $\Delta E(g, p)$ is the energy transition coefficient (transition energy).

The coefficient $P_{R}(A, z)$, which describes the recombination component of radiation losses, is contributed by the dielectronic recombination and the radiation recombination, including cascade transitions. Therefore, we have

$$
\begin{aligned}
& P_{R}(A, z)=\sum_{p} \Delta E(g, p) . \\
& \sum_{n l} \alpha_{\alpha}(g, p ; n l)+\chi \alpha_{c . d}+\chi \beta \alpha_{p},
\end{aligned}
$$

where $\Delta E(g, p)$ is the energy of the stabilizing photon, $\alpha_{\alpha}(g, p ; n l)$ is the rate of dielectronic recombination with capture to a level with quantum numbers $n l ; \chi$ is the ionization potential of the ion formed after recombination; $\alpha_{c . d}$ is the total rate of collisional-dielectronic re- 
combination; $\beta$ is the numerical coefficient $(0.2 \ldots 1)$ that takes into account the thermal energy of electrons participating in the radiation recombination; $\alpha_{p}$ is the total radiative recombination rate.

The third term in eq. (3), $P_{B}(A, z)$, is specified by the bremsstrahlung and, in consequence of its dependence on the squared ion charge, it is the basic function for high-charged ions even in the case of the presence of bound electrons. Considering that the free-free transitions, resulting in bremsstrahlung, occur mainly in the Coulomb field, which is weakly influenced by the distribution of bound electrons, the state (ground or metastable), to which goes the ion, is not substantial [21].

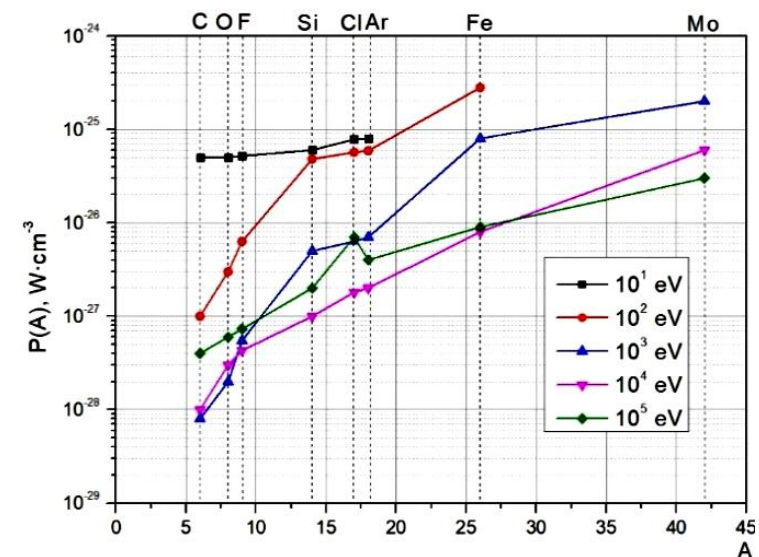

Fig. 1. Radiation-loss power function $P(A)$ for $C, O, F$, $\mathrm{Si}, \mathrm{Cl}, \mathrm{Ar}, \mathrm{Fe}, \mathrm{Mo}$ versus the atomic number of the element for different temperatures of elements

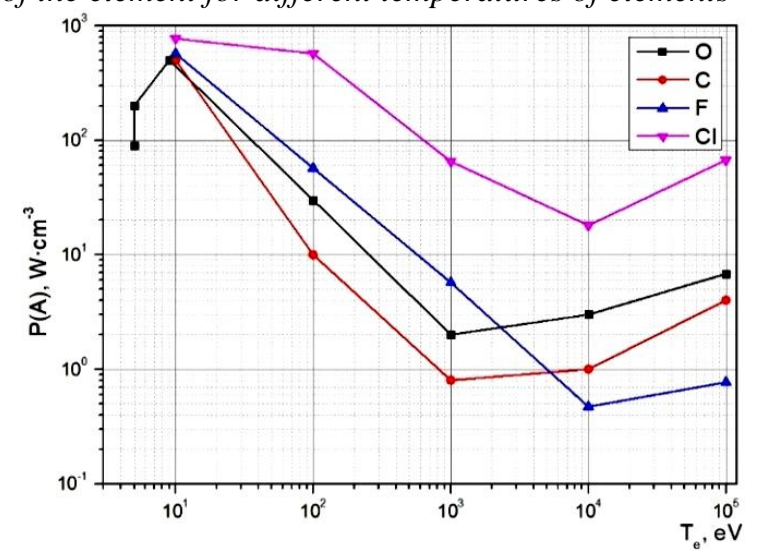

Fig. 2. Specific radiation loss power as a function of electron temperature for different electronegative elements

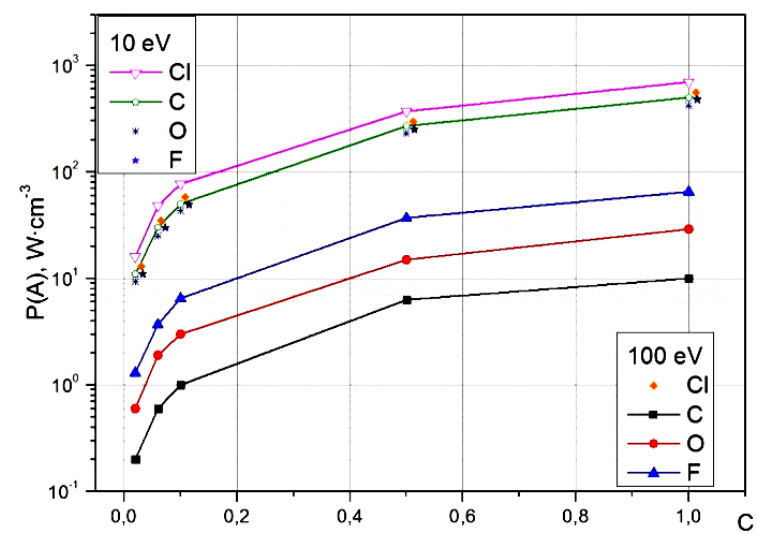

Fig. 3. Specific radiation loss power as a function of impurity particle concentration for different electronegative elements
Fig. 1 shows the radiation-loss power function $P(A)$ versus atomic number of the carbon, oxygen, fluorine, silicon, chromium, argon, iron and molybdenum elements for different electron temperatures (from $10 \mathrm{eV}$ to $10^{5} \mathrm{eV}$ ) in a state of stationary ionization equilibrium. For the small- $z$ elements, e.g., carbon, the function values vary within three orders of magnitude, whereas for (higher-z) molybdenum, the function values vary within one order of magnitude. This is due to the influence of different radiation components (see eq. (5)). For example, the small- $z$ elements are mainly contributed by the line radiation. For higher- $z$ elements, e.g., Mo, the main contribution comes from the bremsstrahlung, which varies monotonically with electron temperature variation. With due regard to the data from ref. [21], Fig. 1, and using eqs. (1), (2) (of the present paper) calculations were made to determine the specific radiation-loss power behavior for four electronegative elements: $\mathrm{C}, \mathrm{O}, \mathrm{F}$, $\mathrm{Cl}$ (Fig. 2). The maximum loss level of about $770 \mathrm{~W} / \mathrm{cm}^{3}$ was registered for $\mathrm{Cl}$ in the electron temperature range from $10^{1}$ to $10^{3} \mathrm{eV}$ at an electron density of $10^{14} \mathrm{~cm}^{-3}$. The minimum power loss values for the other three elements mentioned above lie in the range from 0.4 to $2 \mathrm{~W} / \mathrm{cm}^{3}$. It was also of interest to trace the behavior and variations in specific radiation loss power with impurity particle concentration (Fig. 3) for the same electronegative elements at electron temperatures of 10 and $100 \mathrm{eV}$. The range of these variations is rather narrow (within the range of two tens of $W / \mathrm{cm}^{3}$ for different elements) with the change in the $\mathrm{C}$ impurity concentration from 0.02 to 1.0 for $\mathrm{T}_{\mathrm{e}}=10 \mathrm{eV}$, and is rather wide (within two orders of magnitude) at $T_{e}=100 \mathrm{eV}$.

In conclusion, we note that the knowledge of the radiation power loss under ionization equilibrium conditions may appear useful in: (i) gaining information on the power spectral distribution, (ii) establishing relationship between the total radiation power loss and the intensity of certain number of registered spectral lines, (iii) estimating total energy expenditure for ion production in the specified charge state.

\section{CONCLUSING REMARKS}

1. Specific radiation power losses have been determined for some electronegative elements as functions of the electron temperature and the impurity particle concentration.

2. The maximum radiation-loss power has been registered for chlorine $\left(\leq 770 \mathrm{~W} / \mathrm{cm}^{3}\right)$ at the electron and impurity particle density of $10^{14} \mathrm{~cm}^{-3}$.

3. The minimum radiation-loss power for the other three elements under present study has been found to range from 0.4 to $2 \mathrm{~W} / \mathrm{cm}^{3}$.

4.In studies of the specific radiation power loss versus impurity particle concentration it has been established that the loss variation range is sufficiently compact (within two tens of $\mathrm{W} / \mathrm{cm}^{3}$ for different elements) with change in the concentration from 0.02 to 1.0 at $\mathrm{T}_{\mathrm{e}}=10 \mathrm{eV}$, and is rather wide (within two orders of magnitude) at $\mathrm{T}_{\mathrm{e}}=100 \mathrm{eV}$.

5. Considerable radiation losses associated with the presence of electronegative elements in the interelectrode discharge may lead to destabilization of the latter, to changes in the plasma parameters (density 
and temperature), and eventually, to degradation of the current-voltage characteristic of the plasma current switch. Besides, this imposes additional requirements on the choice and use of dielectric materials in the operating plasma gun structures, which are meant to reduce the amount and concentration of electronegative elements in the discharge gap.

6 . The estimation of the radiation-loss power value will make it possible to gain information on: (i) the power spectral distribution, (ii) the relationship between the total radiation power loss and the intensity of registered spectral lines, (iii) the total energy expenditure for ion production in the specified charge state.

\section{REFERENCES}

1. V.G. Artyukh, E.I. Skibenko, Yu.V. Tkach, V.B. Yuferov. Study of a high-current plasma opening switch: Preprint KIPT 89-28. Kharkiv: NSC KIPT, 1989, p. 12.

2. V.G. Artyukh, E.I. Skibenko, Yu.V. Tkach, V.B. Yuferov. Plasma-vacuum characteristics of a high-speed current switch: Preprint KIPT 94-12. Kharkiv: NSC KIPT, 1994, p. 9.

3. V.G. Artyukh, E.I. Skibenko, Yu.V. Tkach, V.B. Yuferov. Investigation on the possibility of stabilizing the high-speed current switch performance // Ukr. Fiz. Zh. 1995, v. 40, № 8, p. 805-806.

4. E.I. Skibenko, V.B. Yuferov, V.G. Artyukh. A compact electron accelerator "DI" with a high-efficiency plasma current switch // Problems of Atomic Science and Technology. Series "Plasma Physics". 1999, № 3(3), 4(4), p. 236-238.

5. V. Yuferov, E. Skibenko, I. Onishchenko, et al. Investigation of high-current plasma opening switch at low gas pressure. $/ / 12^{\text {th }}$ IEEE International Pulsed Power Conference, Digest of Technical Papers v. 2, Monterey, CA. 1999, p. 1215-1217.

6. E.I. Skibenko, V.B. Yuferov. A compact direct-action electron accelerator with efficient nanosecond plasma-opening switch // Problems of Atomic Science and Technology. Series "Plasma Electronics and New Methods of Acceleration”. 2019, № 4, p. 10-14.

7. E.I. Skibenko, A.N. Ozerov, V.B. Yuferov. Determination of discharge gap conductivity of plasma opening (current) switch // Problems of Atomic Science and Technology. Series "Plasma Electronics and New Methods of Acceleration”. 2019, № 4, p. 3-9.

8. P.F. Goodrich, D.D. Hinchelwood. High-power opening switch operation on "HAWK" // Proc. IX IEEE Intern. Pulsed Power Conf. Albuquerque, 1993, p. 511-515.
9. Earl. W. Mc Daniel. Collision Phenomena in Ionized Gases // John Wiley and Sons, Inc. New YorkLondon-Sydney. 1964, 832 p.

10. C.F. Barnet, M.F. Harrison. Applied atomic collision physics. Plasmas // Academic Press, Inc. 1984.

11. J.B. Hasted. Physics of Atomic Collisions. London Butters Worths. 1964.

12. H. Bohringer, G. Hensler. Metallicity - dependence of radiative cooling in optically thin, hot plasma // Astronomy and Astrophysics. 1989, v. 215, p. 147-149.

13. R. Clark. Radiation raters for low $\mathrm{z}$ impurities in edge plasma // Journal of Nuclear Materials. 1995, v. 220-222, p. 1028-1032.

14. D.E. Past, R.V. Jensen, C.B. Tarter, et al. Steady state radiative cooling rates for low - density, high temperature plasma // Atomic Data and Nuclear Data Tables. 1977, v. 20, 35, p. 397-439.

15. J. Abdallah, Ir., R.E.H. Clark. Calculated radiated power loss for neon, silicon, argon, titanium, and iron // Atomic and Plasma - Material Interaction Data for Fusion. 2003, v. 11, p. 21-47.

16. K.B. Fournier, M.J. Maya, D. Pacellab, et al. Calculation of radiative cooling coefficient for krypton in low density plasma // Nuclear Fusion. 2000, v. 40, № 4, p. 847-864.

17. Yu.V. Kovtun, A.I. Skibenko, E.I. Skibenko, et al. Radiation of multicomponent gas -metal plasma of a pulsed reflex discharge // Problems of Atomic Science and Technology. Series "Plasma Physics". 2010, № 6, p. 171-173.

18. J. Michael Shull and Michael Van Steenberg. The Ionization Equilibrium of Astrophysical Abundant Elements // The Astrophysical Journal Supplements. Series: 48. 1982, January, p. 95-107.

19. P. Mazzotta, G. Mazzitelli, S. Colafrancesco and N. Vittario. Ionization balance for optically thin plasmas: rate coefficients for atoms and of the elements $\mathrm{H}$ to Ni // Astronomy and Astrophysics / ar XIV: astro-ph. / 9806391 V1 30 Jun 1998.

20. S.V. Barakhvostov, I.L. Muzyukin, Yu.N. Vershinin. Peculiarities of energy-mass plasma composition of the coaxial nanosecond surface discharge // ZhTF. 2006, v. 76, iss. 9, p. 46-50.

21. H.P. Summers and R.W.P. Mc Whirter. Radiative power loss from laboratory and astrophysical plasmas I. Power loss from plasmas in steady - state ionization balance // J. Phys. B: Atom. Molec. Phys. 1979, v. 12, № 14, p. 2387-2412.

Article received 19.05.2021 


\title{
ОПРЕДЕЛЕНИЕ ИЗЛУЧАТЕЛЬНЫХ ПОТЕРЬ ПРИ СТОЛКНОВЕНИИ ЭЛЕКТРОНОВ \\ С АТОМАМИ И ИОНАМИ ЭЛЕКТРООТРИЦАТЕЛЬНЫХ ЭЛЕМЕНТОВ В РАЗРЯДАХ ПЛАЗМЕННЫХ КОММУТАТОРОВ ТОКА. ЧАСТЬ ВТОРАЯ
}

\author{
Е.И. Скибенко, В.Б. Юферов, А.Н. Озеров, И.В. Буравилов
}

Определены зависимости удельной мощности потерь на излучение для ряда электроотрицательных элементов $(\mathrm{C}, \mathrm{O}, \mathrm{F}, \mathrm{Cl})$ от температуры электронов и концентрации примесных частиц. Максимальный уровень мощности потерь на излучение зафиксирован для хлора $\left(\leq 770\right.$ Вт/см $\left.{ }^{3}\right)$ при плотности электронов и примесных частиц $10^{14} \mathrm{~cm}^{-3}$. Минимальный уровень мощности потерь на излучение для трех остальных элементов лежит в диапазоне от 0,4 до $2 \mathrm{BT} / \mathrm{cm}^{3}$. Значительные потери на излучение, связанные с наличием в межэлектродном разряде электроотрицательных элементов, могут привести к его дестабилизации и изменению плазменных параметров $\left(\mathrm{n}_{\mathrm{e}}, \mathrm{T}_{\mathrm{e}}\right)$ и, в конечном итоге, к деградации вольт-амперной характеристики плазменного коммутатора тока.

ВИЗНАЧЕННЯ ВИПРОМННЮВАЛЬНИХ ВТРАТ ПРИ ЗІТКНЕННІ ЕЛЕКТРОНІВ

З АТОМАМИ І ІОНАМИ ЕЛЕКТРОНЕГАТИВНИХ ЕЛЕМЕНТІВ У РОЗРЯДАХ ПЛАЗМОВИХ КОМУТАТОРІВ СТРУМУ. ЧАСТИНА ДРУГА

\section{С.І. Скібенко, В.Б. Юферов, О.М. Озеров, І.В. Буравілов}

Визначено залежності питомої потужності втрат на випромінювання для ряду електронегативних елементів (C, O, F, Cl) від температури електронів і концентрації домішкових частинок. Максимальний рівень потужності втрат на випромінювання зафіксований для хлору $\left(\leq 770\right.$ Вт/см $\left.{ }^{3}\right)$ при щільності електронів і домішкових частинок $10^{14} \mathrm{~cm}^{-3}$. Мінімальний рівень потужності втрат на випромінювання для трьох інших елементів лежить у діапазоні від 0,4 до 2 Вт/см³. Значні втрати на випромінювання, пов'язані 3 наявністю в міжелектродному розряді електронегативних елементів, можуть привести до його дестабілізації і зміни плазмових параметрів $\left(\mathrm{n}_{\mathrm{e}}, \mathrm{T}_{\mathrm{e}}\right) \mathrm{i}$, в кінцевому підсумку, до деградації вольт-амперної характеристики плазмового комутатора струму. 